Research Journal of Applied Sciences, Engineering and Technology 6(3): 462-467, 2013

DOI:10.19026/rjaset.6.4102

ISSN: 2040-7459; e-ISSN: 2040-7467

(C) 2013 Maxwell Scientific Organization Corp.

\begin{tabular}{lll}
\hline Submitted: August 24, 2012 & Accepted: September 24, 2012 & Published: June 15, 2013
\end{tabular}

\title{
Research Article \\ Research on the Influence of Accountants' Human Capital Factors on Profit Manipulation Based on Data Envelopment Analysis
}

\author{
Yinqiu Wang \\ Tourism College of Zhejiang, Hangzhou 311231, China
}

\begin{abstract}
This study focuses on the investigation of the influence of human factors on the profit manipulation. Literature review indicated that although earning management and profit manipulation has been discussed in previous study, little study has done in the investigation of the influence of human factors. To address this issue, this study has developed a new analysis model based on the Data Envelopment Analysis (DEA) to assess the influence of human factors on profit manipulation. The innovation lies in that the education level of the accountants, the accountant number and the gender of the executors have been analyzed using the DEA to determine their influence on the profit manipulation. Empirical analysis has been carried out by the use of historical data of Hangzhou City, China. The DEA analysis results show that the profit manipulation is influenced significantly by the factors of the education level and number of the accountants. Hence, to constrain the illegal profit manipulation, it is essential to improve the education level of the accountants and control their number. The findings of this study contribute to the body of knowledge in the earning management and can be referred in the profit manipulation control.
\end{abstract}

Keywords: Accounting, data envelopment analysis, human factors, profit manipulation

\section{INTRODUCTION}

Up to date, China's capital market is not matured yet, information disclosure system is not perfect and accounting standards is so elastic that companies lack regulation. The interests of stakeholders will be greatly damaged if profits are manipulated and financial statements are forged. Therefore, by gathering recognizing indicators of list companies of profit manipulations and building a recognizing model, it has realistic meanings to regulate Chinese security market and maintain interests of stakeholders. The key issue to address this problem is to collect and sort data of companies to determine distinguished influence factors.

In the early 1980s, Western world began to investigate earnings management. Relevant literature shows that, the research on the earnings management is the pioneer of the research about profit operation. The measurement model of earnings management is the foundation of the recognition model of profit manipulation. Healy (1985) took the lead in the measurement model of earnings management. He suggested that profits should be quantified, which is the foundation for the measurement of earnings management method and also provide the basis for the recognition model of profit manipulation. Then, many scholars have researched measurement model of earnings management and representative models include Healy model (Healy, 1985), Deangelo model (Deangelo, 1986), Jones model (Jones, 1991), random model ( $\mathrm{Li}, 2003)$, etc. Meanwhile, the studies on the profit manipulation have also received a lot of attentions. In fact, there is no rigorous distinction in concept between earnings management and profit manipulation. The special earnings management refers that the profit is not against the accounting principles, but only changes the surplus in the distribution of different accounting period. The generalized earnings management has extensive meaning. On the basis of the concept in the narrow sense, it also includes profit manipulation, accounting fraud, etc. However, little study has been done to investigate the problem of profit manipulation and accounting fraud in the field of earnings management. Healy and Wahlen (1999) reviewed the earnings management. The relevant theory of the earnings management in the application of accounting standards formulation was reviewed. Empirical analysis was carried out under accrual accounting on aspects of methods, degree and frequency of earnings management and the influence of distribution of interests in the earnings management was also discussed. Elias (2002) suggested that earnings management is the activity of choosing different accounting standards for accounting adjustment. His research showed that when considering the long-term benefits in accounting adjustment and in the moral allowed range, earnings management has positive role to adjust action; when considering short-term behavior and beyond the moral bound, earnings management becomes the profit manipulation. Mohanram (2003) studied the difference between earnings management and profit manipulation and pointed out that the

This work is licensed under a Creative Commons Attribution 4.0 International License (URL: http://creativecommons.org/licenses/by/4.0/). 
earnings management is not necessarily through the illegal accounting for profit manipulation. His study presented the reason and means of earnings management, as well as how to quantitatively measure the earnings management value through accounting methods. Kadan and Yang (2005) studied the earnings management from both theoretical and empirical on the influence of the share price and analyzed the earnings management before and after the change of share price. Their research showed that enterprise earnings management will increase the value of enterprise and the effect of earnings management will lag 1 to 4 years. Thus the use different accounting standards will produce different influence on its share price. Bergstresser and Philippon (2006) studied the relationship between personnel's bonus plan and earnings management. Through the analysis the company executives bonus amounts and company profit control condition in 1990, it found that profits manipulate trends to happen when the relationship of executive bonuses and stock price is very closer. Saleh et al. (2005) took Malaysia's a company for example, pointed out that corporate governance including supervision to the board of directors, the audit committee and the external auditor. The research indicated that, in a given company the profits manipulate has negative correlation with the chief executive. Zhang and Wang (2007) studied the relationship between earnings management and corporate governance through the analysis of the acquiring company. Their research showed that in the company acquiring, if the company's long-term performance and management level improved, the merger and acquisition was motivated by good intentions, while if the two indexes decreased profit manipulation behavior may be obvious. Demski (2008) reviewed the earnings management of all kinds of empirical research and models. It pointed out that the influence behaviors on corporate value can be divided into three kinds: benign earnings management can reflect the company's long-term value; malignant earnings management will cover the company's shortterm value; neutral earnings management can reveal the real value of the short-term. Weil (2009) gave the quality earnings concept, namely in considering the company operating cycle and published financial statements under the condition of the time, the choice of appropriate accounting standards on earnings management. He pointed out that in choose different accounting standards companies usually change the income statement items through the earnings management. Shah et al. (2009) studied the relationship between the corporate governance and earnings management through the analysis of 2006 listed companies. With the improved Jones model, it calculated the listed company's accrued profit and correlation between earnings management and corporate governance. On the basis of empirical analysis of the Pakistan companies, they issued the profit manipulation situation. The results showed that the playability accrued profit is the results of profit manipulation. Igan and Pinheiro (2010) constructed the identification model of profit manipulation and investigated effect of the company internal ownership on profitability decision. They further pointed out that companies with weak corporate governance level are prone to profit manipulation. These researches provide abundant insight into the understanding of profit manipulation and earnings management. However, very littler study has addressed the issue of influence factor on the profit manipulation, much less in the investigation on the influence of the human resources on the profit manipulation. In factor, the human resources have significant influence on the profit manipulation. In particularly, the education level of the accountants, accountant numbers and the gender of the executors, etc., impact the earnings management greatly. As a result, it is very urgency to investigate these human factors on the probability of profit manipulation.

This study conducts empirical analysis to address the issue of the influence of human factors on the profit manipulation process. The Data Envelopment Analysis (DEA) method has been employed to analyze the influence of the education levels of the accountants, the accountant numbers and the gender of the executors on the probability of profit manipulation. The innovation of this study is that it is the first time to investigate the influence of human factors in the profit manipulation research. Empirical analysis has been conducted by the use of historical data of Hangzhou City, China. The analysis results demonstrate that the education level and number of the accountants play a significant impact on the profit manipulation in Hangzhou, China. Finally, to improve the earnings management, some solution policies have been suggested to control the profit manipulation.

\section{INTRODUCTION OF PROFIT MANIPULATION}

Profit manipulation: According to literature, the profit manipulation can be divided into three categories: white, grey and black (Demski, 2008). The white class is a beneficial profit manipulation behavior, which can improve the information transparency of the financial report. The black class is a malignant profit manipulation behavior, which refers to the use of misleading or fraud and other means to change accounting data. The grey class refers to manipulate behavior that complies with fair accounting standards permitted within the scope of financial report. Hence, the definition of profit manipulation includes earnings management and illegal manipulation.

\section{Reason of profit manipulation:}

Immature capital market: China's capital market start very late and there exist defects on the structure. As a result, the immature capital market and irregular 
management policy created conditions for profit manipulation.

Imperfect information disclosure system: Although the accounting information disclosure has been expanded in a certain extent under the new enterprise accounting standards, there has shortage in the financial information disclosure and needs further improvement. In addition, the new enterprise accounting standards cannot get effective execution, which leads to ineffective supervision on company profit manipulation behavior.

Large accounting standards elastic: New accounting standards gives enterprise managers more accounting policy choice, makes the accounting personnel use more professional judgment in dealing with accounting events and hence increases the subjective factors on enterprise accounting policy choice. Thus, it creates space for the company profit manipulation.

Weak corporate governance level: Under the right separation of company ownership and management, on the one hand, the company's division of labor is more explicit and hence improves the company's efficiency. On the other hand, it creates the conflicts of interests between owners and managers.

The results of the profit manipulation not only cause real profits losses, but also lead to false accounting elements in enterprise financial report assets, liabilities and rights and interests. Hence, the calculation results of various financial indexes cannot reflect the actual status of the enterprise, leading to distortion of the accounting information. Hence, it is imperative to investigate the profit manipulation. It can be noticed that the accounting information is one main reason for the profit manipulation and up to date little study has reported the influence of accounting information on the profit manipulation, thus it is very reasonable to research the influence of human factors of accounting information on the profit manipulation.

\section{THE DATA ENVELOPMENT ANALYSIS (DEA) MODEL}

Introduction of DEA: Data Envelopment Analysis (DEA) is a kind of statistical analysis (Jahanshahloo et al., 2011). DEA can use the input-output data to estimate whether the efficient of input or output. Against to other statistical analysis methods, DEA have its own features shown as follows (Mahdiloo et al., 2011):
- DEA can deal with multiple inputs and outputs by the use of Decision Making Unit (DMU)

- DEA is easily for the performance evaluation

- DEA does not require prior information

- DEA can eliminate subjective factors

Classical DEA model is the Constant Return to Scale (CRS) model (Charnes et al., 1978). Let the input variables of the DEA is $I=\left[i_{1}, i_{2}, \ldots, i_{n}\right]$ and the output is $\mathrm{O}=\left[\mathrm{o}_{1}, \mathrm{o}_{2}, \ldots, \mathrm{o}_{\mathrm{n}}\right]$, then the relationship of input variables and output variables can be expressed as:

$$
\theta=\frac{\mu^{T} I}{\gamma^{T} O}
$$

where,

$\theta \quad$ : The relative efficiency of DMU $\left(\mathrm{i}_{\mathrm{p}}, \mathrm{O}_{\mathrm{p}}\right)$ to other DMUs

$\mu \& \gamma$ : The weight matrixes of the input and output, respectively

The meaning of the DEA model is to find the appropriate $\mu$ and $\gamma$ to make the relative efficiency of $\operatorname{DMU}\left(\mathrm{i}_{\mathrm{p}}, \mathrm{O}_{\mathrm{p}}\right)$ be the largest one. Then, Eq. (1) should subject to the following constrains:

$$
\left\{\begin{array}{l}
\max (\theta)=\frac{\mu^{T} I}{\gamma^{T} O} \\
\text { s.t } \frac{\mu^{T} i_{q}}{\gamma^{T} o_{q}} \leq 1,(q=1,2, \ldots, \mathrm{N}) \\
\mu \geq 0, v \geq 0
\end{array}\right.
$$

To simply the calculation, Eq. (2) can be rewritten as:

$$
\left\{\begin{array}{c}
\text { s.t } \quad \sum_{q=1}^{n} \lambda_{q} i_{q}+s^{-}=\theta i_{p} \\
\sum_{q=1}^{n} \lambda_{q} o_{q}-s^{+}=o_{p} \\
\lambda_{q} \geq 0 ; s^{+}, s^{-} \geq 0
\end{array}\right.
$$

where,

$\lambda=$ The optimal solution for the DEA model

$\mathrm{s}^{-} \& \mathrm{~s}^{+}=$The relax coefficients for the input and output, respectively

If add the following constrain in Eq. (3):

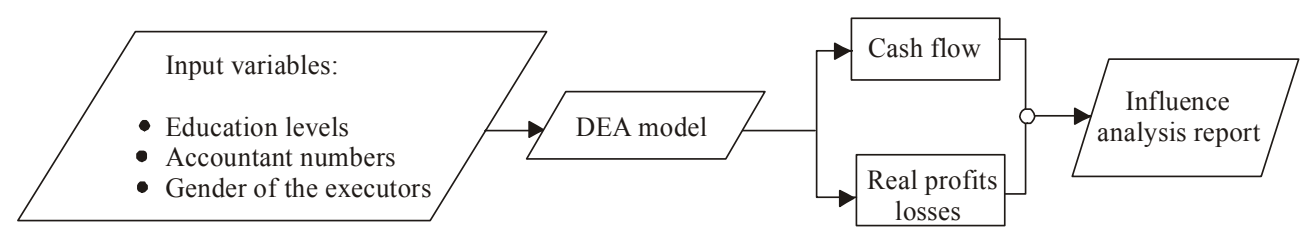

Fig. 1: Diagram of the proposed DEA model 
Res. J. Appl. Sci. Eng. Technol., 6(3): 462-467, 2013

$$
\sum_{q=1}^{n} \lambda_{q}=1
$$

Then we obtain the Variable Return to Scale (VRS) model (Banker et al., 1984). VRS model is usually used to investigate the technical efficiency of DMUS. Because this study aims to research the influence of human factors, the VRS model has been employed in the DEA analysis.

The input and output of the DEA model: A new analysis model is established in this study. In this analysis model, the human factors are the inputs of the DEA model and the outputs are the cash flow of the profit manipulation and the real profits losses.

The education levels of the accountants: The education conditions influence the accountants' ability significantly. Whether accountants with high education or low education are the critical factor to profit manipulation needs empirical analysis.

The accountant numbers: Large number of accountants may influence their efficiency. It also creates space for profit manipulation. Hence, it is worthy to investigate the contribution of accountant numbers in the profit manipulation.

The gender of the executors: Executors usually make the decisions of profit manipulation. The gender of executors may vary in their tendencies in the profit manipulation.

The diagram of the proposed DEA model is shown in Fig. 1.

\section{EMPIRICAL ANALYSIS}

Profit manipulation has been found in many companies in China. Discussion on the identification and regulation of profit manipulation has been reported in some recent study. However, the human factors involved with the identification and regulation of profit manipulation have not taken into account in previous studies. In order to evaluate the contribution of human factors to the profit manipulation, this study takes the statistical data of Hangzhou city to conduct the DEA analysis and reveal the influence mechanics of the human factors on the profit manipulation.

The statistical data on the financial report of 50 companies from Hangzhou city during 2009 to 2011

Table 1: Characteristics of education levels of the statistical data

\begin{tabular}{lllll}
\hline & \multicolumn{2}{l}{ Education levels } & & \\
& & & & $\begin{array}{l}\text { College degree } \\
\text { or below (\%) }\end{array}$ \\
Years & Ph. D (\%) & Ms. D (\%) & Bs. D (\%) \\
\hline 2009 & 3.3 & 21.7 & 61.3 & 13.7 \\
2010 & 5.5 & 29.5 & 56.5 & 8.5 \\
2011 & 8.3 & 31.7 & 53.7 & 4.3 \\
\hline
\end{tabular}

Table 2: Characteristics of the statistical data

\begin{tabular}{|c|c|c|c|c|}
\hline \multirow[b]{2}{*}{ Years } & \multirow{2}{*}{$\begin{array}{l}\text { Accountant } \\
\text { number }\end{array}$} & \multicolumn{2}{|c|}{ Gender of executor } & \multirow{2}{*}{$\begin{array}{l}\text { Real profit } \\
\text { loss (million } \\
\text { dollars) }\end{array}$} \\
\hline & & Male & Female & \\
\hline 2009 & 6173 & 461 & 39 & 247 \\
\hline 2010 & 6729 & 435 & 65 & 315 \\
\hline 2011 & 6286 & 411 & 89 & 253 \\
\hline
\end{tabular}

has been adopted in the DEA analysis in this study. Table 1 and 2 show the characteristics of the data.

It can be seen in Table 1 that the majority of the education levels is the Bachelor degree. It maintains around $55 \%$ of education level of the accountants. For higher education level, the percentage of the master degree is about $1 / 5$. The highest education level (i.e., the Philosophiae Doctors) and the low education level (College Degree or below) grasp a small pieces of the accountants' education levels. Hence, the higher education levels need to be improved for the tested companies and the education level of the accountants is at or just beyond average.

Table 2 shows that the accountant numbers have certain impact on the profit manipulation. In 2009 and 2011, accountant numbers are almost equal to each other while in 2010 the accountant number is much larger. Correspondingly, the real profit losses caused by the profit manipulation in 2009 and 2011 are obvious smaller than that in 2010. As for the gender of

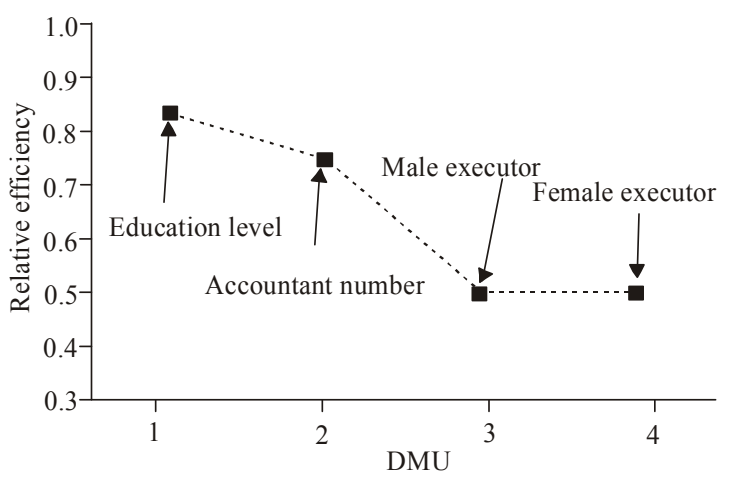

Fig. 2: Relative efficiency of the influence of human factors in the input analysis

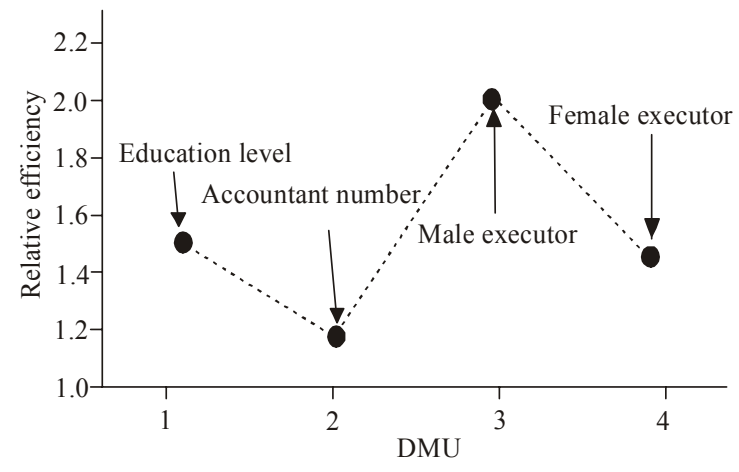

Fig. 3: Relative efficiency of the influence of human factors in the output analysis 
executors, it can be seen in the table that the number of female executors increases gradually. However, it is difficult to assess the impact of the increased female executor number on the real profit losses.

To assess and reveal the influence of the mentioned human factors on the profit manipulation, the DEA with VRS strategy has been used to investigate the statistical data of Hangzhou in this study. In the DEA processing, both the input analysis and output analysis have been implemented. Figure 2 and 3 show the DEA analysis results, where the relative efficiencies of the four DMUs have been displayed.

It can be seen in Fig. 1 that in the input analysis the relative efficiency of education level of the accountants is larger than the other three factors. This means the factor of education level of the accountants is the critical one in the profit manipulation. The company with poor education level of the accountants may be more likely to choose profit manipulation. As a result, the education level should be improved to restrain the profit manipulation to decrease the real profit losses. It also can be noticed that the relative efficiency of number of the accountants is the second largest one. Hence, this factor contributes a certain impact on the profit manipulation. The smallest value of the relative efficiency belongs to the factor of the gender of executors.

In the output analysis in Fig. 2, one can be noticed that the largest value of relative efficiency is the factor of male executors. This is means male executors are less sensitive than the other factors and keep rational thinking in the choosing of profit manipulation. The company with male executors may avoid conducting illegal profit manipulation. In contrast, the factor of number of the accountants presents more active in the profit manipulation. It scores the smallest relative efficiency. This result is conformed to the observation of Table 2. The number of the accountants influences the profit manipulation to a fair degree. It is therefore, imperative to control the number of the accountants. It also can be noticed that the relative efficiency of education level of the accountants is the second smallest one. This means this factor influences the profit manipulation significantly. This result agrees well with the analysis in Fig. 1. Hence, it can be drawn that the education level and number of the accountants play a significant impact on the profit manipulation. Improving the education level of the accountants and constraining their number can enhance the earning management in a company.

\section{CONCLUSION AND RECOMMENDATIONS}

A new Data Envelopment Analysis (DEA) model has been proposed to investigate the influence of education level of the accountants, the accountant number and the gender of the executors on the profit manipulation in this study. Empirical analysis has been conducted on the historical data of Hangzhou City, China. The analysis results demonstrate that the education level and number of the accountants are the key factors influencing the profit manipulation. Hence, to improve the effectiveness of earning management and decrease illegal profit manipulation, it is reasonable to implement the following solution strategies:

- Promote accountants quality and build suitable personnel management construction

- Perfect accounting supervision system and improve information disclosure system

- Increase the cost of illegal profit manipulation

\section{REFERENCES}

Banker, R., A. Charnes and W. Cooper, 1984. Some methods for estimating technical and scale inefficiencies in data envelopment analysis. Manag. Sci., 30(9): 1078-1092.

Bergstresser, D. and T. Philippon, 2006. CEO incentives and earnings management. J. Financ. Econ., 80: 511-529.

Charnes, A., W. Cooper and E. Rhodes, 1978. Measuring the efficiency of decision making units. Eur. J. Oper. Res., 2(6): 429-444.

Deangelo, L., 1986. Accounting numbers as market valuation substitutes: A study of management buyouts of public shareholders. Account. Rev., 61: 400-420.

Demski, J., 2008. Earnings Management: Emerging Insights in Theory, Practice and Research. New York University, New York, pp: 25-38.

Elias, Z., 2002. Determinants of earnings management ethics among accountants. J. Bus. Ethics, 1: 33-45.

Healy, M., 1985. The effect of bonus schemes on accounting decisions. J. Account. Econ., 7: 85-107.

Healy, M. and M. Wahlen, 1999. A review of the earnings management literature and its implications for standard setting. Account. Horizons, 4: 365-383.

Igan, D. and M. Pinheiro, 2010. Incentive to manipulate earnings and its connection to analysts' forecasts, trading and corporate governance. J. Econ. Financ., 4: $1-41$.

Jahanshahloo, G., F. Lotfi, Y. Jafari and R. Maddahi, 2011. Selecting symmetric weights as a secondary goal in DEA cross-efficiency evaluation. Appl. Math. Model., 35(1): 544-549.

Jones, J., 1991. Earnings management during import relief investigations. J. Account. Res., 29: 193-228.

Kadan, O. and J. Yang, 2005. Executive Stock Options and Earnings Management: A Theoretical and Empirical Analysis. Studying study. Indiana Bloomington, IN. 
Li, X., 2003. Profit control measurement model and its application. Financ. Account. Mon., 10: 6-8.

Mahdiloo, M., A. Noorizadeh and F.R. Saen, 2011. A new approach for considering a dual-role factor in supplier selection problem. Int. J. Acad. Res., 3: 261-266.

Mohanram, P.S., 2003. How to manage earnings management? The Institute of Chartered Financial Analysts of India, 10: 1-4.

Saleh, N., T. Iskandar and M. Rahmat, 2005. Earnings management and board characteristics: Evidence from Malaysia. J. Pengurusan, 24: 77-103.
Shah, S., S. Butt and A. Hasan, 2009. Corporate governance and earnings management an empirical evidence form Pakistani listed companies. Eur. J. Sci. Res., 26(4): 624-638.

Weil, R., 2009. Quality of earnings and earnings management: A primer for audit committee members. Financ. Account., 9: 1-3.

Zhang, J.J. and X. Wang, 2007. Searching for the motives and effectiveness of Chinese mergers and acquisitions. Ph.D. Thesis, the University of Hong Kong, Hong Kong, pp: 2-7. 